\title{
COMPARATIVE ANALYSIS OF POLITENESS STRATEGIES IN RUSSIAN AND ENGLISH DENTISTRY TEXTS
}

\author{
Ivan Grigoriev, Svetlana Rubtsova \\ St Petersburg University, Russia
}

\begin{abstract}
The paper compares two corpora of Russian and English research articles in dentistry to identify differences between texts as regards evaluative language and other language tools to pursue politeness strategies. Positive politeness strategies are understood as a part of the positive evaluation process having the pragmatic function not to offence each other's desire to be approved of. The study aims to define the politeness strategies that are most commonly used in Russian and English medical journals and to focus on the possible reasons for differences in Russian and Anglo-Saxon academic writing cultures that underlie the choice of politeness strategies. The analysis of the data shows that Russian research articles rarely employ politeness strategies if compared to their English counterpart preferring negative politeness strategies to positive ones. This study also provides some methodological advice for developing a syllabus in academic writing. Conclusions made on the basis of two compared corpora can also provide insights into both translation and contrastive studies.
\end{abstract}

Key words: politeness strategies, evaluation, discursive pragmatics, corpus, mitigation devices

\section{INTRODUCTION}

In the modern multilingual environment, texts produced by L2 scholars significantly outnumber research written by L1 scholars (Hyland, 2016). Inevitably academic texts written in English become the battleground for different written discourse practices originating from different disciplinary norms and different linguacultural traditions. The situation presupposes the constant need to research into the factors that influence L2 scholars linguistic and discursive choice (Shchemeleva, 2019; Tusting et al., 2019) and the upsurge in the amount of research into different aspects of written and oral academic communication.

Evaluation is a very important and a commonly shared feature of academic research. The term 'evaluation' was initially interchangeably used along with 'modality', 'appraisal', 'stance', and 'evidentiality' (Thompson, Hunston, 2000), which overlap more or less in the research of different authors, being sometimes used as synonyms. Until recently, one of the most popular terms has been 'epistemic' and 'attitudinal stance' by Conrad and Biber [16]. Without going into the detailed analysis of the history of theoretical approaches to the evaluation, after Mauranen (2002: 270) and Thompson \&

Submitted November $11^{\text {th }}, 2020$, accepted for publication February $24^{\text {th }}, 2021$

Corresponding author: Ivan Grigoriev. St. Petersburg University, Russia| E-mail: i.grigorev@spbu.ru 
Hunston (2000) evaluation for us is a 'broad cover term for the expression of the speaker's or writer's attitude or stance towards, viewpoint on, or feelings about the entities or propositions'. We agree to consider stance as a broader term that encompasses the notion of evaluation (Alba-Juez, Thompson, 2014), which is a 'verbal realization or manifestation of stance'. Thus evaluation should have explicit manifestation at the lexical, morphological, syntactical or semantical level. Moreover, we consider modality as a subcategory of evaluation and not as a separate category (Giannoni, 2005). The evaluation is not only considered to show the opinion of the author towards the propositions that are expressed in academic texts, but it also presents the axiological scale of academic views and beliefs that underlie this opinion.

\section{Negative AND Positive Evaluation}

In general, evaluation, even if taking into consideration the definition we provided in the previous passage, is considered to be a blurred term for linguistic research because it cannot be attributed to a fixed collection of linguistic devices (Mauranen, 2003). However, some approaches to its conceptualization seem to be a part of every research in a certain field as it is considered to be a 'ubiquitous feature of human interaction and, despite its apparently impersonal facade, central to academic writing (Alba-Juez, Thompson, 2014). In a broad sense, evaluation is understood as a personal attitude of the author displayed by different language tools in the text and, traditionally, two major domains of evaluation may be determined. First, the domain of opinion that is expressed towards something expressed by the author indicating the degree on the axiological axis "bad-good". The second domain covers the degree of credibility or evidentiality that is invested into the truth value of the proposition. Expressing the opinion is a complex act that includes the creation of a value-system, which in turn, reflects the personal beliefs in a certain field, the values of a professional group and is considered to be discipline and genre oriented or oriented towards a different discourse community.

Naturally, both domains demonstrate an axiological hierarchy ranging from negative to positive evaluation. Both perform different functions that go beyond the establishment of the truth value of the proposition of the statement thus contributing to the creation of new knowledge. Positive evaluation, we believe, seems to have additional functions of creating rapport with the academic community, presenting a personal opinion and interacting with the readers (Kunyarut, 2014: 159). Positive evaluation seems to be more explicit than negative evaluation [1, 13]. However, this situation according to Mauranen (2002) may result in blurring the real pragmatics of evaluation, for example, when the task for the novice is to find out what is really wrong with the research.

The research into the evaluation of written academic discourse is not scarce and demonstrate quite a long history (Hyland, 1996; Hyland, Diani, 2009; Hood, 2010) with very little done as regards oral academic discourse (Mauranen, A. 2002). Hence discourse and argumentative functions of evaluation are no longer a ground for academic debate. 'New' developments tend to involve a comparative study of English with other languages: Spanish, French, Thai, Norwegian, Bulgarian and Japanese (Vold, 2006; Moreno, Suárez, 2009; Kunyarut, 2014; Salager-Meyer et al, 2007; Itakura, Tsui, 2011; Itakura, 2013.; Vassileva, 2001). For the most part, research involves the creation of comparable corpora with subcorpora for compared languages. 
The conceptualization of evaluative acts or units which are understood not as grammar or lexical units but as functional units serving the purpose of presenting critical comments to academic texts gives us two simple categories often described as praise and criticism or negative and positive evaluation or negative vs. positive critical comments (Thompson, G., Hunston, 2000). It is only natural that the axiological evaluation presupposes that there are different degrees of positiveness or negativity that are essential to the units to which an axiological pattern can be applied and there is a hierarchy in axiological dimensions (Alba-Juez, Thompson, 2014). However, all the degrees of negativity and positiveness are grouped into two categories which are researched separately or simultaneously with regard to the chosen linguistic and discursive reality, with negative evaluation attracting more attention than positive (Principle, 2000; Giannoni, 2005). The reason why research in negative evaluation outnumbers that of a positive one is likely to be stated by Navarro who asserted that negative evaluation is a fundamental element of academic discourse (Navarro, 2016).

Rhetorical tendencies, disciplinary and discursive differences constitute the major part of research in the field. Moreover, it is now universally agreed that there tends to be a cultural difference in expressing praise and criticism in different linguistic cultures (Itakura, 2013). However, the research in this field is still scarce and mostly concentrates on Anglo-American socio-pragmatic conventions.

Rhetorical tendencies are studied to find out how different evaluative acts distribute along different academic genres and across different writing cultures (Moreno, Suárez, 2009; Yakhontova, 2002), quantitative contrastive analysis of moves structure in terms of evaluative acts distribution through the moves of the academic work of different academic genres is performed (Fortanet, 2008). We found a lot of research on finding disciplinary differences in discursive strategies arguing for example that when reviewing previous research linguistics are inclined to express much more criticism than economists and historians (Diani, G. 2009).

The use of evaluative acts in pursuing discursive strategies is another important field of research. One of the most important strategies for academic written discourse is the strategy of being polite, thus producing rapport with the reader.

\section{Politeness STRATEGy}

Following Brown and Levinson (1987), the notion of face was developed which is considered to be 'the universal feature of communication' (Brown and Levinson, 1987), otherwise stated, not to offend each other's desire to be approved of. The notion of 'pragmatic politeness' then was categorized into 'negative face - the want of every competent adult member that his actions be unimpeded by others and positive face - the want of every member that his wants be desirable to at least some others' (Brown and Levinson, 1987: 312). The author also came up with the typology of politeness strategies or preferences in terms of language devices they employ. Academic research that follows this publication (Walko, 2007; Shaw, 2003; Gil-Salom, Soler-Monreal, 2009) examines both positive and negative politeness strategies with the help of corpus analysis of a particular language, their balance in academic texts under investigation, particular mitigation devices and cumulative effect in combination of these strategies. Positive politeness strategies include maintaining common ground and the sharing of feelings, emotions, limitations and difficulties, and expressing solidarity with the readers, assuming collaboration, seeking agreement. Among 
negative politeness strategies, the most important strategies to mention: vagueness and depersonalization that reduce the writer's commitment to claims (Gil-Salom, Soler-Monreal, 2009: 188).

There is yet little research comparing and contrasting politeness strategies in academic discourse. Following Brown and Levinson's typological approach Kunyarut (2014) researched Thai students conventions in 'the use of politeness strategies in discussion sections of research papers' (Kunyarut, 2014: 159) finding which of them are most preferable. The study not only found patterns and regularities in the use of two strategies but also concluded that discourse regularities in the use of politeness strategies result from the wrong understanding of academic writing as a presenting 'collection of facts', without considering the reader as a part of discourse (Kunyarut, 2014: 165). We believe these teaching implications are very important not only for English language teaching but in a broad sense for understanding better any language - to - language transposition. According to Z. Walko (2007) the authors employ different sets of politeness strategies in different genres of academic research. Even inside one genre authors tend to use different arrays of strategies. These strategies are grouped by the author according to the following model: 'establishing conceptual framework (introduction, rationale, methods), describing the setting and the participants; data analysis; conclusions and implications' (Walko, 2007: 16). For each stage employed politeness strategies are described. Gil-Salom, and Soler-Monreal (2009) agree with the general typology of politeness strategy of Brown and Levinson applying them to discussion sections of engineering research articles. However, the regularities that were found during the analysis does not have statistical support thus not allowing the reader to understand the discursive strategies of their use.

Detailed investigation in different aspects of politeness strategies include Harwood's (Harwood, 2005) investigation into the pragmatic functions of pronouns in academic texts as part of stating 'common ground' strategy or 'common quest for scientific truths' (Harwood, 2005: 346); research of the use of epistemic modality markers as a mitigation device for a researcher to avoid imposition (Myers, 1989: 9; Yang et al., 2015); research of the impersonality structures (Martinez, 2001: 227) that allow authors to disassociate themselves from the information they present, in other words, to express negative politeness strategy.

\section{RESEARCH QUESTION}

As an academic text requires that the writer should present his claim and contradict to the previous research, the face-threatening act towards the chosen opponent is unavoidable. Consequently, to maintain academic communication respect and recognition are to be demonstrated. Depending on general academic, disciplinary specific and broad discursive community culture there can be found many linguistic tools (realizations) of mitigation policies i.e. politeness strategies. The main area of applying the evaluation and its pragmatic use in pursuing politeness policies is the discussion section in research articles, which is intended to uncover the soundness of the research and justification for new knowledge.

Previous contrastive research that involved few languages into the research studying cultural, disciplinary and language differences mostly concentrate on this section. Other areas with the extensive use of politeness strategies are literature review, introduction and conclusion. However, in the overall picture of the strategies employed, it is important to 
understand the national writing conventions, disciplinary national writing conventions and possible solutions to overcome writing manners that contradict international academic writing conventions for the research to be published in English and to prevent cultural misunderstanding and misjudgment.

We found only a little research into different languages that try to give a comprehensive picture of pragmatic politeness strategy used in a certain language. Pragmatic strategies of evaluation were rarely investigated in Slavonic languages in general and in Russian academic discourse in particular. However, linguacultural features of Russian academic texts due to the long history of language isolation from international academic landscape seem to be important to understand regularities in violation of academic conventions.

RQ1: Research question: Are there differences in the distribution of politeness strategies in Russian and English dentistry journals?

RQ2: Are there statistical differences in the distribution of positive and negative politeness strategies?

RQ3: What are the possible reasons for differences in Russian and Anglo-Saxon writing cultures that underlie the choice of politeness strategies?

\section{METHODS AND DATA}

As a source material, we randomly selected 37 journal research articles in English and Russian published in mainstream English and Russian medical journals during the last 15 years. The corpus consists of 116,351 words. Following Brown and Levinson's (1978, 1987) models of politeness strategies adopted in the later research by Getham, Walko and Salom we compiled the list of strategies and sub-strategies. We annotated the corpus and marked up language devices for each strategy and sub-strategies. Then to avoid imbalance of subcorpora we calculated the number of occurrences and normalized raw frequency per 1,000 words as the standard length of medical papers differ for the languages under research. English papers show an average of 4051 words and Russian papers - 2504 words. Further statistical evaluation was made according to the mean value and standard deviations.

\section{RESULTS}

The comparative frequencies of English and Russian politeness strategies are shown in Tables 1 and 2.

Table 1 Averages of positive politeness strategies

\begin{tabular}{|l|c|c|c|c|}
\hline & \multicolumn{2}{|c|}{ English Sub-corpus } & \multicolumn{2}{c|}{ Russian Sub-corpus } \\
\hline Sub-strategies & Mean & SD & Mean & SD \\
\hline Speculative claims & .03 & .20 & .09 & .27 \\
Certainty adjectives & .19 & .42 & .11 & .30 \\
Modifiers & .24 & .21 & .23 & .22 \\
Total for the first sub-strategy & .22 & .39 & .18 & .36 \\
Stance adjectives and adverbs & .06 & .14 & .07 & .41 \\
Instructing the reader & 0.7 & .24 & .05 & .28 \\
Total for the second sub-strategy & .09 & .48 & .03 & .34 \\
\hline
\end{tabular}


Positive politeness strategies showing that the writer shares the same ideas with the reader are represented by two sub-strategies:

First sub-strategy 'showing common views, attitudes and opinions' by the use of:

A. Modifiers assuming common ground like important, significant, key, vital, topical:

$V$ sovremennoj koncepcii ortodontii ustranenie esteticheskih narushenij yavlyaetsya vazhnym rezul'tatom effektivnogo lecheniya. (RAS3-r, 1)

'According to the modern concept of ortodontiya the elimination of aesthetic defects is an important result of efficient treatment.'

Poisk metodov, pozvolyayushchih kolichestvenno ocenivat' eti yavleniya, ostaetsya aktual'noj problemoj stomatologii. (RAS19-r, 22)

'Finding methods that allow to quantitatively assess these phenomena problem of dental science continue to be the topical problem of dentistry.

Here we find approximate parity in the use of modifiers - 0,24 vs. 0,23.

B. Certainty adjectives like 'clear, obvious, definite' and others are used much more often in English corpus than in Russian with the ratio 0,19 to 0,11:

Na stepen' razvitiya zabolevaniya, ochevidno, okazyvayut vozdejstvie $i$ drugie faktory, takie kak soputstvuyushchaya somaticheskaya patologiya. (RAS6-r, 390)

'Evidently other factors like concomitant somatic pathology'.

Conventional complete maxillary dentures undoubtedly remain a viable and preferred therapeutic option. (RAS4-e, 283)

For periodontal maintenance, it is also established that the risk of clinical attachment breakdown is not fixed or absolute. (RAS5-e, 198)

For Russian corpus izvestno (is known) accounts for the majority of all the cases.

C. Speculative claims expressed by the words like assumption, assume, speculate, speculation or equivalent phrases:

Imeetsya predpolozhenie, chto Porphyromonas gingivalis, Prevotella intermedia produciruyut KCZHK. (RWAS4, 68)

'There is an assumption that Porphyromonas gingivalis, Prevotella intermedia produciruyut KCZHK.'

The authors speculated that this increase in composite resin... (RAS4-e, 309)

English sub-corpus shows much less of such expressions if compared to Russian corpus: .03 vs .09 .

The second politeness strategy 'creating rapport with the reader by showing personal attitude' is followed by:

A. Instructing the reader by the use of imperatives:

Neobhodimo otmetit', chto znacheniya pokazatelej indeksa SZHK. (RAS18-r, 150)...

'It is necessary to note that values of SZHK index ...'

Sleduet takzhe ob-ratit' vnimanie na to, chto bol'shinstvo odnokomponentnyh adgezivov VI pokoleniya. (RAS7-r, 18)

Note that a history of periodontal disease increases the levels of peri-implant mucositis and periimplantitis. (Ras4-e, 333)

The English corpus provides few examples of imperatives use, slightly outnumbering occurrences of imperatives in Russian sub-corpus.

B. The use of stance adjectives and adverbs that can be found only in English corpus:

Interestingly, the effect of PM recall interval on periodontal health has been studied in the past. (RAS5-e) 
It is noteworthy that adherence of RPD patients to oral hygiene and denture hygiene instruction. (RAS9-e, 716)

Russian writers would much prefer to present 'common ground in the form of common attitude, opinions and views' just by presenting the fact as a matter of course and formally having no traces of any politeness strategy:

$V$ poslednie gody poyavilis' novatorskie tekhnologii - razlichnye metodiki napravlennoj regeneracii tkanej. (RAS15-r, 9)

'Innovative techniques have appeared recently including different methods of controlled tissues regeneration.'

In Russian corpus, this strategy of constructing common ground with the reader by presenting the fact as certainly true without any modality or stance markers occurs three times more often than the same strategy in English corpus. Moreover, in English tradition, if compared to Russian, these sentences are very likely to be followed by citation marks. Active construction is preferred very rarely, with the subject denoting the live actor of the research:

Vse chashche vrachi i issledovateli ispol'zuyut termin "galitoz" (halitosis). (RWAS4, 68).

'Doctors and researchers are now increasingly using the term halitosis.'

Table 2 shows the distribution of negative politeness strategies in sub-corpuses.

Table 2 Averages of negative politeness strategies

\begin{tabular}{|l|c|c|c|c|}
\hline & \multicolumn{2}{|c|}{ English Sub-corpus } & \multicolumn{2}{c|}{ Russian Sub-corpus } \\
\hline Sub-strategies & Mean & SD & Mean & SD \\
\hline Hedging by modals & 8.9 & 4.8 & 1.7 & .5 \\
Hedging by reporting verbs & .9 & .23 & .34 & .26 \\
Total for the first sub-strategy & .23 & .28 & .38 & .27 \\
Attribution of responsibility & .06 & .14 & .01 & .31 \\
Depersonalisation & 2.7 & .13 & 5.6 & .17 \\
Total for the second sub-strategy & 8.3 & .32 & 13.4 & .16 \\
Personalisation & .14 & .37 & .20 & .36 \\
\hline
\end{tabular}

Negative Politeness Strategies showing that the writer attempts to reduce his commitments to claims are represented by two sub-strategies. The first strategy 'showing that claims are provisional or temporary by hedging' is pursued through:

A. Modals or equivalent expressions (conditionals, phrases like 'be likely, probably'): $V$ kachestve primera mozhno privesti formirovanie faktorov. (RAS17-r, 82)

'As an example, one may mention the formation of factors.'

Na osnove matematicheskogo modelirovaniya dannyh ekspress-skrininga vrach poluchaet vozmozhnost' postavit' diagnoz. (RAS17-r, 91)

'Basing on mathematical modelling of the data of express-screening the doctor seizes an opportunity to make a diagnose.'

Well-localised lesions without previous embolisation are therefore ideal, as they are likely to have smaller feeder vessels. (RAS-e 6, 486)

Hedging by the use of non-infinitive forms of modal verbs is quite rare:

But could be important given that adequate nutritional intake is particularly important in people with diabetes. (RAS9-e.717) 
English corpus demonstrates the use of modals that occurs more than five times as often as the use of modals in Russian corpus, the range of modal verbs being very diverse (may, can, should, need, must) compared to Russian mozhno (can, may). Hedging by the use of conditional was found only in EC (English corpus):

Given that profilometry is the most frequently used in vitro method of reporting surface change, plotting a bearing area ratio curve from existing profilometric data would perhaps produce a more meaningful description of the surface. (RAS10-e, 189)

B. The use of reporting verbs with the difference lying in the ratio of their occurrence in corpora, which accounts for 2,5:1 with English corpus containing two and a half times more reporting verbs.

The following reporting verbs were found:

Russian corpus: schitat' (think) - believing, konstatirovat' (note, state) - presenting, predlagat' (propose) rekomendovat' (recommend) - suggesting, vyyasnyat' (find out) concluding, ukazyvat' (indicate, specify) - presenting, priznavat' (accept, recognize) agreeing. English corpus: show, reporting, stating, reveal - presenting, suggest, theorizing, postulate - suggesting, consider, evaluate - evaluating, highlight emphasizing, question - disagreeing, agree - admitting, conceding, confirm - agreeing. Russian authors do not tend to use reporting verbs with the meaning of evaluating, emphasizing, and disagreeing. At the same time, we can see that Russian reporting verbs express only neutral position.

The second negative politeness strategy shows 'you do not want to impose' includes the following sub-strategies:

A. Attribution of responsibility to the objectivity of the results presented by other authors by the use of the following phrases: these observations suggest, these results imply, or, for Russian tradition, appealing to the overwhelming opinion of majority:

Odnako po mneniyu mnogih issledovatelej izmeneniya. (RAS8-r, 483)

'However, according to (in opinion of) many scholars, changes...'

Such reference to the opinion of the majority is quite rare as it surpasses the boundaries of tentativeness and requires from the author further reasoning.

Na osnove matematicheskogo modelirovaniya dannyh ekspress-skrininga vrach poluchaet vozmozhnost' postavit' diagnoz. (RAS17-r, 91)

'Based on mathematical modelling of the data of express-screening the doctor seizes an opportunity to make a diagnosis (diagnose).'

Although recent advances and improved multidisciplinary approaches to care suggest this can be much improved upon in the future. (RAS8-e, 482)

B. Depersonalisation by the use of passive constructions without an agent:

$V$ hode issledovanij bylo vyyavleno, chto v organizme delenie kletok ... (RAS15-r, 10)

'In the course of research, it was disclosed that the cell division in an organism ...'

For direct restorations, USPHS or Ryge criteria were published, with modified versions still being used today to assess various features of restorations. (RAS8-e, 482)

This strategy is most commonly used in both corpora with citation marks being more often used in English corpus.

Standing apart is the negative politeness strategy of "Personalisation" that attributes all responsibility to the author or authors of the research by utilizing exclusive first person pronouns or expressions which we feel as equivalent to the expression of personal pronoun (authors): 
$V$ svyazi s etim dannyh pacientov my otnesli $k$ gruppe riska razvitiya KPL SOR. (RAS18-r)

'Accordingly, these patients were classified as a risk group for the development of KPL SOR.'

It is the authors' view that although obliteration of the nidus through embolization may prevent revascularisation, guaranteed curative intervention must include... (RAS8-e, 486)

In this review, we have considered only those trials that compared osteotomy with the piezoelectric device and osteotomy... (RAS10-e, 1077)

The statistics show the slight predominance of the strategy in Russian corpus over English.

\section{DISCUSSION AND LIMITATIONS}

We tried to build up comparable corpora of two languages: Russian and English, with English corpus consisting of world-leading dentistry journals indexed in Elsevier. However, the counterpart national academic landscape is still in the process of adapting itself to international publishing conventions. As a result, only limited number of Russian publications in dentistry are available from internationally recognized sources, which could influence the results of the calculations.

The present study was designed to determine the distribution of politeness strategies across two languages. Seemingly, the differences in the distribution of politeness strategies in Russian and English dentistry journals are quite clear, which is also true for the differences in the distribution of positive and negative politeness strategies. Comparing positive politeness strategies in two languages showed the big difference in their distribution and the use of linguistic means to express them. English academic texts demonstrate the wider palette of devices covering all the sub-strategies that were selected for the analysis. The only exception is the first sub-strategy 'showing common views, attitudes and opinions' by the use of modifiers assuming common ground (important, significant, key, vital, topical) which shows the same distribution for both corpora. Possibly this represents the universality feature of medical academic discourse.

Quite evidently, significant differences in discursive strategies we found in our research of negative politeness strategies. An illustrative example here is the distribution of modals and reporting verbs in the English corpus. Interestingly, the modals occur more than five times as seldom as they occur in Russian corpus; with reporting verbs occurring two and a half times as seldom as in Russian corpus. The ideal that might underlie this is that Russian researchers may not be so interested in presenting the shades of their opinion due to the inheritance of national writing conventions.

The results of this study are in line with the conclusions made by Yakhontova (2006) and Shchemeleva (2015) who show significant differences in Anglo-American and Russian traditions of research writing. The research follows the tradition of the research in 'culture-specific' and disciplinary differences of academic texts indicating that the process of globalization has not yet and possibly never will erase the cultural specificity of presenting research in English. However, the major weakness of similar research that yet a lot is to be done to separate all the influencing factors including language, culture and disciplinary traditions. 


\section{CONCLUSION}

Our research has shown statistical distribution of politeness strategies in English and Russian dentistry corpora. Some of the regularities (the use of impersonal constructions) presumably have universal nature for academic genres in English and Slavonic languages. Others, like the use of non-evaluative language in establishing common ground with the reader, seems to be very oriented towards national genre traditions and presumably will hamper the publication process in international academia.

In terms of pedagogy, introducing L2 writing into the academic classroom by showing students rhetorical strategies, in our case - politeness strategies, of academic writing gives way to "examining how the evaluation process, particularly as a window into the social process by which knowledge is created, can be taught by developing a series of evaluative materials' (Bloch, 2003). Still, we can find only few research to that effect.

We also might conclude that for universal integration of academic cultures for a L2 researcher it is vitally important to adopt traditions of evaluation and the paradigm of politeness strategies through understanding not only the pragmatics of targeted academic discourse but also local written conventions of academic discourse in their own language. Contrastive studies are likely to serve as an effective tool to demonstrate that in order to reach endorsement or approval of the readers.

\section{REFERENCES}

Alba-Juez, L., Thompson, G. 2014. The many faces and phases of evaluation. Alba-Juez, L. Thompson, G. (eds.), Evaluation in context. John Benjamins Publishing Co, 3-27.

Biber, D. 2006. Stance in spoken and written university registers. Journal of English for Academic Purposes, 5(2), 97-116.

Bloch, J. 2003. Creating materials for teaching evaluation in academic writing: using letters to the editor in L2 composition courses. English for specific purposes, 22, 347-354.

Brown P., Levinson, S. C. 1987. Politeness: some universals in language usage. Cambridge. Cambridge University Press.

Diani, G. 2009. Reporting and evaluation in English book review articles: A crossdisciplinary study. Hyland, K. et al. (eds), Academic Evaluation.

Fortanet, I. 2008. Evaluative language in peer review referee reports. Journal of English for Academic Purposes, 7, 27-37.

Giannoni, D. S. 2005. Negative evaluation in academic discourse. A Comparison of English and Italian research articles. Linguistica e Filologia, 20, 71-99.

Gil-Salom, L., Soler-Monreal, C. 2009. Interacting with the Reader: Politeness Strategies in Engineering Research Article Discussions. IJES, Special Issue, 175-189.

Halliday, M. A. K. 1994. An Introduction to functional grammar. London: Edward Arnold.

Harwood, N. 2005. 'We do not seem to have a theory. The theory I present here attempts to fill this gap': Inclusive and exclusive pronouns in academic writing. Applied Linguistics, 26/3, 343-375. doi:10.1093/applin/ami012

Hood, S. 2010. Appraising research: evaluation in academic writing, Palgrave Macmillan.

Hyland, K. 1996. Writing without conviction: Hedging in science research articles. Applied Linguistics, 17(4), 433-454.

Hyland, K. 2000. Disciplinary discourses: Social interaction in academic writing. London: Longman. 
Hyland, K. 2016. Academic publishing and the myth of linguistic injustice. Journal of Second Language Writing, 31, 58-69.

Hyland, K., Diani, G. (eds.), 2009. Academic Evaluation. Review genres in university settings. Palgrave Macmillan.

Itakura, H. 2013. Hedging praise in English and Japanese book reviews. Journal of Pragmatics, 45, 131-148.

Itakura, H., Tsui, A. B. M. 2011. Evaluation in academic discourse: Managing criticism in Japanese and English book reviews. Journal of Pragmatics, 43(5), 1366-1379.

Kunyarut, G. 2014. Politeness strategies in Thai graduate research paper discussions: Implications for second/foreign language academic writing. English Language Teaching, 7(11), 159-167.

Martinez, I. A. 2001. Impersonality in the research article as revealed by analysis of the transitivity structure. English for specific purposes, 20, 227-247.

Mauranen, A. 2002. "A Good Question”. Expressing evaluation in academic speech. In: Domain-specific English. Textual practices across communities and classrooms. Cortese, G., Riley, P. (eds), Frankfurt: Peter Lang, 115-140.

Mauranen, A. 2003. Editorial. Evaluative language use in academic discourse. Journal of English for Academic Purposes, 2, 269-271.

Moreno, A. I., Suárez, L. 2008. A study of critical attitude across English and Spanish academic book reviews. Journal of English for Academic Purposes, 7(1), 15-26.

Myers, G.A. 1989. The pragmatics of politeness in scientific articles. Applied Linguistics, $10(1), 1-35$.

Navarro, F. 2016. The critical act as a pragmatic unit for studying academic conflict. A methodological framework. Salager-Meyer, F., Lewin B. A. (eds.) Crossed words: Criticism in scholarly writing, 23-55.

Principle, P. 2000. Negative evaluation in academic discourse. 71-100.

Salager-Meyer, F., Lewin, B. 2011. (eds.), Crossed words: criticism in scholarly writing, Peter Lang AG, International Academic Publishers, Bern.

Shaw, P. 2003. Evaluation and promotion across languages. Journal of English for Academic purposes, 2, 343-357.

Shchemeleva, I. 2015. The Janus moment in EAP: revisiting the past and building the Future. Proceedings of the 2013 BALEAP conference. Reading. Garnet education, 179-187.

Shchemeleva, I. 2019. 'It seems plausible to maintain that...': Clusters of epistemic stance expressions in written academic ELF texts. ESP Today, 7(1), 24-43.

Thompson, G., Hunston, S. 2000. Evaluation: an introduction. Hunston, S., Thompson, G. (eds.), Evaluation in text: authorial stance and the construction of discourse. 1-27. Oxford: Oxford University Press.

Tusting, K., McCulloch, S., Bhatt, I., Hamilton, M., Barton, D. 2019. Academic writing: The dynamics of knowledge creation. London; New York: Routledge.

Vassileva, I. 2001. Commitment and detachment in English and Bulgarian academic writing. English for Specific Purposes, 20(1), 83-102.

Vold, E. T. 2006. Epistemic modality markers in research articles: a cross-linguistic and cross disciplinary study. International Journal of Applied Linguistics, 16(1), 61-87. https://doi.org/10.1111/j.1473-4192.2006.00106.x

Walko, Z. 2007. EFL research articles through the lens of pragmatic politeness. WoPalP, $1,1-16$. 
Yakhontova, T. 2002. 'Selling' or 'telling': the issue of cultural variation in research genres. Flowerdew J. (ed.), Academic discourse, 216-232. London: Longman.

Yakhontova, T. 2006. Cultural and disciplinary variation in academic discourse: The issue of influencing factors. Journal of English for Academic Purposes, 5, 153-167.

Yang, A., Zheng, S., Ge, G. 2015. Epistemic modality in English-medium medical research articles: A systemic functional perspective. English for Specific Purposes, 38, 1-10. 